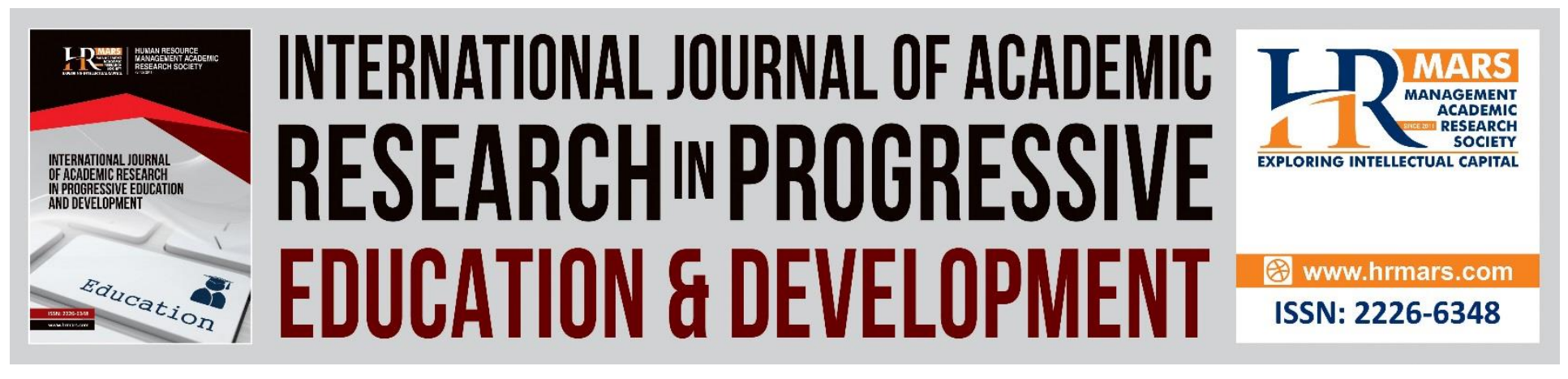

\title{
The Importance of Information Literacy to Support Lifelong Learning in Convergence Era
}

Saiful Farik Mat Yatin Saifudin Salim, Mohd Fakrullah Mahmood, Aryanti Binti Ahmad

To Link this Article: http://dx.doi.org/10.6007/IJARPED/v7-i3/4372 DOI: $10.6007 /$ IJARPED/v7-i3/4372

Received: 04 June 2018, Revised: 19 June 2018, Accepted: 09 July 2018

Published Online: 24 July 2018

In-Text Citation: (Salim, Mahmood, \& Ahmad, 2018)

To Cite this Article: Salim, S. F. M. Y. S., Mahmood, M. F., \& Ahmad, A. B. (2018). The Importance of Information Literacy to Support Lifelong Learning in Convergence Era. International Journal of Academic Research in Progressive Education and Development, 7(3), 352-362.

\section{Copyright: (C) 2018 The Author(s)}

Published by Human Resource Management Academic Research Society (www.hrmars.com)

This article is published under the Creative Commons Attribution (CC BY 4.0) license. Anyone may reproduce, distribute, translate and create derivative works of this article (for both commercial and non-commercial purposes), subject to full attribution to the original publication and authors. The full terms of this license may be seen

at: http://creativecommons.org/licences/by/4.0/legalcode

Vol. 7, No. 3, July 2018, Pg. 352 - 362

http://hrmars.com/index.php/pages/detail/IJARPED

JOURNAL HOMEPAGE

Full Terms \& Conditions of access and use can be found at http://hrmars.com/index.php/pages/detail/publication-ethics 


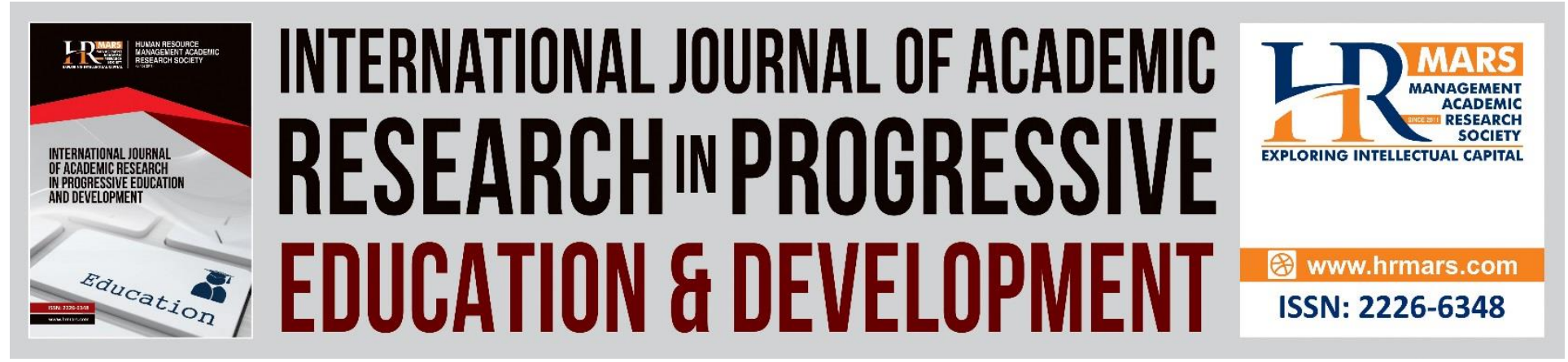

\title{
The Importance of Information Literacy to Support Lifelong Learning in Convergence Era
}

\author{
Saiful Farik Mat Yatin Saifudin Salim, Mohd Fakrullah Mahmood, \\ Aryanti Binti Ahmad \\ Faculty of Information Management, Puncak Perdana Campus, \\ UiTM Selangor, Malaysia
}

\begin{abstract}
In this information technology world today, information plays a prominent role every one relies on it. Information come from paper, sound, visual, images-based material and also it may be in the form of oral, written or image. This paper describes a meaning of Information Literacy (IL) and Lifelong Learning (LL). It also emphasis on relationship between IL and LL in convergence era. In education, it is supported as the backbone to every happening. In the age of $L L, I L$ is an important skill to move ahead across the globe, flooded with information in an unprecedented way. The information literate, has an ability to take informed decisions or solve their problems and know how to learn. IL is an enabler to touch all the dimensions of learning and it is the key to success of anyone's life in the information society. This paper describes the relation between IL in support LL among society. Information skills are needed for creating information literate culture. IL is a continuously learning process from early age until older. Information Professionals (IP) are responsible to encourage community in implementation of IL. Because it can help the expansion of knowledge and creation of new knowledge, whether it is for educational or personal reasons. Keywords: Information Literacy, Information Skills, Lifelong Learning, Self-efficacy, Library Science

\section{Introduction}

Information has become a source most important of the world's economies and of course a fundamental component within education. Information is the most important element of technological and scientific change. It presents some challenges to individuals from all walks of life: the students, employees, and all types of citizens. Information load now requires people review and assess information to verify their reliability. Information is an elusive concept and there is a continuing debate about its meaning, relationship and its correlation such as knowledge, expertise, learning process and cognitive psychology. This paper will discuss the term in its widest sense that include all kinds of facts and understanding that related with the organizational management that concerned with data, factual knowledge, opinions and
\end{abstract}




\section{INTERNATIONAL JOURNAL OF ACADEMIC RESEARCH IN PROGRESSIVE EDUCATION AND}

DEVELOPMENT

Vol. 7, No. 3, July 2018, E-ISSN: 2226-6348 @ 2018 HRMARS

evaluations. The valuable information can be show when the human can have perceived and interpreted that information. To develop skills, knowledge and wisdom, the important thing is information which has been the raw materials for the mind. Information is defined as the meaning that a human assign to data by means of conventions used in their presentation. As Meadow and Yuan (1997) observe, the word "information" is often used to describe data sets and data streams. The term "information science" is less than fifty years old, having been coined as recently as 1955 (Wilson, 1999). In the information world, the function of information is referring to the one implication which has been impact to the situation and gives different meaning.

This paper describes about the attitude of society in providing information literacy. Other than that, it also discusses about the tools and media that society use to support lifelong learning process in digital age. The advent of convergence era, media and information literacy are focused on producing knowledge that encourages society in supporting lifelong learning process. Other than knowledge of a society itself, a contribution of media also plays an important aspect to generate a knowledge society rather that information society. Although, the process of information literacy is coming from an early education, teachers can use a media in encourage teenagers to share their knowledge among them. It consists of teaching concepts and strategies to encourage students in using media to access and retrieve information that they need in proper way.

The using of media in information literacy involve the ability of people to utilize the layout of multimedia interaction which encompasses skills for reading, writing and calculating with all available tools in digital format (Frau-Meigs, 2012). In facing a digital environment, people should change their information literacy activities from print-based culture to media culture that encourage the socialization of young people on digital networks in support lifelong learning process from younger to elder. In order to provide information literacy among society, the mindset of using traditionally method in dissemination of information should change in using a media tools to compete with digital environments.

Media education and information literacy both came together in supporting lifelong learning activities among society. A media plays as a provider that society will use in develop information literacy program. As broadcast, audiovisual and media content and information literacy could hardly remain separate. Information literacy is linked with the use of media literacy to enhance an ability to manipulate technology to find information efficiently and effectively that meet the society need. It consists of interaction between human-computer interactions. The rapid changes of media and technology will encourage society become more information literate in identify useful information can encourage society more knowledgeable. Consequently, the term information literacy not only focus on reading and writing only but it covers the process of searching and using information that involve the media tools to get the right information and disseminate it to the right person. Using a technology also involves the ability of society in understanding a skill in access information that available in a digital format. A convergence era enables society to implement skills in using technology and media to create an information literate society in lifelong learning process 
Vol. 7, No. 3, July 2018, E-ISSN: 2226-6348 @ 2018 HRMARS

\section{Information Literacy}

Generally, IL is a set of abilities that required a person to identify when information is needed and the ability to locate manipulate and use effectively the information that they need. IL can be defined as a process for problem solving for their information needs by applying a systematic approach to locating, placing, applying, and synthesizing information and evaluating the overall process in terms of effectiveness and efficiency (Businessdictionary.com). IL is the tools can be used to solve the problems which need special skills (American Library Association, 2000).

The notion of IL, originally conceptualized in the 1970s (Bundy, 2004), is now commonly used to describe the skill set required to interact effectively in the electronic environment. To achieve the mission, IL must be through the process which includes theory and applied the understanding to meet the various terminological and conceptual relationships to support lifelong learning (Shapiro and Hughes, 1996; Snavely and Cooper, 1997, Pawley, 2003).

\section{Lifelong Learning}

$\mathrm{LL}$ is a broad term that basically difficulty to define with specifies definition. Some people think that early learning and schooling can give the impact of IL. From that situation, IL can move to the global concept which can help for growing of the nation in political, economy priorities, and with cultural and social value systems. In support LL among society, information skills are needed to encourage society to get the right information that they need. Society must knowledgeable in searching and retrieve information to become information literate. LL cannot be easily defined. LL can describe "learning that continues throughout a lifetime". But this is a simple and general definition, which simply repeats the very words one is trying to define. The good definition comes from Maehl (2003) assertion that LL is a "broad generic term that is difficult to define with specificity".

Bundy (2004) defines the relationship between IL and LL as follows. "IL is the foundation for the independent learning and LL." Relationship between IL and education is well covered by the statement such as, "IL as a catalyst for educational change" (Bruce, 2008) or "IL as a prerequisite for LL", this are the basically technic to explain and promote the concept of IL.

This relationship has been supported by the numerous investigations and studies which state that the success and the effective of learning depends on the skills to manage the information like access, evaluate, communicate and the ethic's in using information (Limberg, 1999; Kuhlthau, 2004; Bruce, 2000).

\section{Convergence Era}

Convergence can be defined as new a phenomenon which is technological capabilities that only recently established to allow for widespread implementation. The simple theory of convergence allows multiple tasks to be performed on a single device, which effectively decrease an human interaction (Technopedia.com). In the contexts of information literacy, convergence is related with the technology and media use in support continues of lifelong learning. Using technology nowadays will shift the classical information literacy to digital information literacy. These situations will radically changing environments that cause the using of technology in information literacy process. 
Vol. 7, No. 3, July 2018, E-ISSN: 2226-6348 @ 2018 HRMARS

IL with the Application of Socio-Cultural Approach

In the new era of information today, there are many challenges to get the information today because information comes from many sources. All the sources must be filtered and manage carefully to get the quality of the information. The skills to locate, evaluate and use information is very important especially impact of the explosion of online library and Internet resources. IL skills normally provide user to manage the information from many sources to process that information to be useful information. The library's shared facilities and services in Florida are not surprising because there is a school library, public library and community college that can be used together (Woods, 2001), Colorado (Dornseif and Willis, 1999; Reno, 1999; Nichols, 2002), and more extensively in Australia (Aird et al., 1998; Dunford, 1998; Bundy, 1998; Bannister, 1999). To create the awareness of IL, it should be cultivated from primary school student. IL self-efficacy among students is differing according to gender, level of foreign language, field of interest, the number of books they read and level of research skills.

\section{IL Skills for the LL}

The basic scope of IL is reading and writing but when digital information come today IL must added digital, computer, visual, media, network and library literacy. IL is the term being applied to the skills of information problem solving (American Library Association, 2000). IL skills come from learning and using the tools, techniques and methods. These skills can help student to recognize a need for information and they can construct strategy to locate and accessing information. IL self-efficacy among student either in school or university is in medium level because the lack of information skills that becomes a challenge in accessing information that they need with the rapid growth of technologies. LL required skills in seeking information with the changes of technologies, use of the information need and sharing it among students. The skills or strategies in obtaining information are called Information Literacy (IL).

IL can help to expansion of knowledge and creation of new knowledge, whether it is for educational or personal reasons. Besides, LL is one educational activities in everywhere and for every person which can help people to gain their knowledge and skills and also assist them to the part of social transformation and integrated them into the society (Demiralay and Karadeniz, 2008; Demirel, 2009; Jarvis, 2009). We need it to become informed, lifelong learners. In doing a research skill also infect the IL self-efficacy because students will continuously seek information that related with their subject and coped with the rapid flow of information.

\section{IL in Sociocultural Theory}

IL research and IL integration practices sociocultural theory and their application are related. In the socio-cultural theory it shows that knowledge is the relationship between others of people which consider by the individual or group members. Social constructivist paradigm which considers sharing knowledge through interaction among group members by the individuals is one of the sociocultural theories (Bryman, 2001). In the collaborative environment the interaction between learner and other people, objects and events can describe as sociocultural theories which overview on their learning and development process (Vygotsky, 1978).

In 1920s and 1930s at Russia, Vygotsky and his associates were the first systematized and applied this sociocultural theory (John-Steiner and Mahn, 1996). Lev Vygotsky was a Russian 
INTERNATIONAL JOURNAL OF ACADEMIC RESEARCH IN PROGRESSIVE EDUCATION AND DEVELOPMENT

Vol. 7, No. 3, July 2018, E-ISSN: 2226-6348 @ 2018 HRMARS

psychologist and educator who died in 1934 in his late 30's of tuberculosis "without the world understanding or accepting the sociocultural theory that he nearly single-handedly constructed" (Whiteside, 2007: 48). His translated seminal works, Mind in society (Vygotsky, 1978) and Thought and language (Vygotsky, 1986) addressed the critical importance of social and cultural context to human cognitive development. Sociocultural theories have been further developed by other theoreticians such as Lave $(1988,1991)$; Lemke $(1990)$; Rogoff $(1990,2003)$ and Wertsch (1991).

The Important of Self-efficacy

Self-efficacy consists of emotions and actions of a person that will be the totality of human behavior (Koul and Rubba, 1999; Cassidy and Eachus, 1998). Self-efficacy can show the confident level in abilities of individual to successfully perform a certain behavior or task (Cassidy and Eachus, 1998). Bandura (1977) describe that self-efficacy is the ability of a person in managing and determining actions to achieve the target. Nowadays, people usually take a little action if they believe that the task given is exceed their capabilities to perform rather that a task that they already expert and they believe that they will performed well to produce the desired outcome (Bandura, 1977, 1986; Cassidy and Eachus, 1998; Koul and Rubba, 1999; Pajares, 2002).

However, in developing of IL self-efficacy, students should have activities to improve their LL skills. To encourage IL self-efficacy, teacher should become information literate in creating $\mathrm{LL}$ tendency and determining a prospective teacher's. Researchers belief that the higher-level sense of efficacy will give a big impact to the effort, persistence, and resilience (Kear, 2000; Pajares, 2002), in influencing information problem solving, learning and teaching process, and lifelonglearning activities. Bandura (1986) has underlines that individuals who have a strong sense of self-efficacy will equip themselves to rely on their own initiative. It shows that a strong selfefficacy will give an impact to accomplish LL from IL process or activities among individual or society.

\section{Roles of IL}

In this community, the process of learning and knowing can be defined as a process of searching the right information among and librarians to supported and assisted the researchers and academicians needs in doing their research (Nuthall, 1997). IL integration gives researchers a lot of knowledge. Zhong and Alexander (2007); Cherry, Rollins, and Evans (2013) reported that students who fully using library services and resources such as database, research tools, interlibrary loans get highly chances in improving their learning development phase. It related with the members of community included librarian, researcher, student advisors in implementation of information literacy in supporting lifelong learning. In IL integration community practice, they share and expertise among them collaborated and co-constructed of IL integration that have interrelationship with IL curricular design in education environment.

IL communities should be working in groups by create their own knowledge and expertise in supporting learning process among student by providing appropriate teaching materials (Coolahan, 2002: Chang et al., 2012). Teachers must prepare themselves with the rapid growth of information by identify the necessary information that student needs to become information literate (Diehm and Lupton 2014), and improve their self-efficacy level.

Students should familiar with using search engine in acquiring information for information literacy activities for continues learning in education environment and the process (Wilkes and 
Vol. 7, No. 3, July 2018, E-ISSN: 2226-6348 @ 2018 HRMARS

Gurney, 2009; Johnston, 2010; Koltay et al., 2010; Ladbrook and Prober, 2011; Salisbury and Karasmanis, 2011). Many researchers believe that only certain students have the skills and knowledge to produce useful information and can only be done by a student with the ability, ability and skill in managing information (Rowlands et al., 2008; Bennett et al., 2008; Cunningham, 2010; Hargittai, 2010). Besides that, only a little portion of students know how to use the search engine in acquiring information, access the reliability of information sources and identify and using the proper citations (Ladbrook and Prober, 2011; Salisbury and Karasmanis, 2011; Toteng et al., 2011). The practices of IL among the communities must have researcher and participants who expert in learning process to create IL curricular design. New adaption of IL should be implementing in the curriculum structure and development process should be continuously improvised to support students in their learning process.

\section{Discussion and Recommendation}

In general, lifelong learning is a process that derived from a positive mind and attitude of a person in information literate. The curiosity for knowledge has changed a person perception to gain knowledge in supporting lifelong learning process.

Both IL and LL are:

1. Self-motivated and self-directed:

An individual should have encouraged themselves with their own motivation that doesn't involve the mediation of others.

2. Self-empowering:

They are willing to helping others to become information literate regarding the social and economic status, gender, religion, race and ethnic background in supporting society to improve their life with knowledge.

3. Self-actuating:

An individual who can sustains a good information literacy and practices the lifelong learning process can be used an entire of life.

Harnessed together, IL and LL can improve the:

1. Lifelong learning will offer a set of choices and chances for individual to sharing an information that improve personal, family and societal matters.

2. Quality of education for both formal and informal from early school setting until working environment that support the job training and produce a quality staff.

3. With the blended of information literacy and lifelong learning process, it will encourage an individual to improve their career with a reward, making a right decision in business performance.

4. An individual will effectively participate in social and cultural environment, either local or higher level of community to fulfill the professional goals in supporting a lifelong learning process.

\section{Conclusion}

As a conclusion, IL is a "set of skills", that can be improved depends on individual needs. The skills include an attitude in learning process, modified the resources, technique and methods in using 
Vol. 7, No. 3, July 2018, E-ISSN: 2226-6348 @ 2018 HRMARS

information and online tutorial. IL skills are very important for $\mathrm{LL}$ and also an important application in socio-cultural society development. IL and LL have a strong relationship in improved a society to be an information literate. An individual can encourage others to become information literate, but they have no guarantee that other will use the information or sharing it in their life time. But, at the same time, a person can implement lifelong learning their life without become information literate. There is a positive relationship between LL tendency and IL selfefficacy. Implementation of IL self-efficacy should be done since primary education and prospective teachers should motivate in using their learning skill and techniques. In addition, the process of problem solving behaviors of individual id depends on self-efficacy beliefs that support the lifelong learning process. Relationships between knowledge and community are related. Support from knowledgably person also has an impact on their IL systems.

\section{References}

American Library Association (2000), Information Literacy: A Position Paper on Information

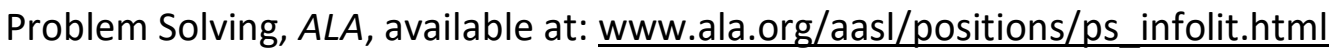

Bannister, M. (1999), "Joint use libraries critical success factors-reflection on practice", Orana, Vol. 35 No. 2, pp. 15-18. Bundy, A. (1998), "Widening client horizons: joint use public libraries in the 1990s", Australasian Public Libraries and Information Services, Vol. 11 No. 1, pp. 4-16.

Bandura, A. (1977), "Self-efficacy: toward a unifying theory of behaviour change", Psychological Review, Vol. 84, pp. 191-215.

Bandura, A. (1986), Social Foundations of Thought and Action: A Social Cognitive Theory, PrenticeHall, Englewood Cliffs, NJ.

Bennett, S., Maton, K. and Kervin, L. (2008), "The 'digital natives' debate: a critical review of the evidence", British Journal of Educational Technology, Vol. 39 No. 5, pp. 775-786.

Bruce, C. (2008), "Information literacy as a catalyst for educational change: a background paper", white paper prepared for UNESCO, the US National Commission on Libraries and Information Science, and the National Forum on Information Literacy, for use at the Information Literacy Meeting of Experts, Prague, The Czech Republic, available at: www.nclis.gov/libinter/infolitconf\&meet/papers/bruce-fullpaper.pdf (accessed 25 July 2008).

Bryman, A. (2001). Social research methods. Oxford: Oxford University Press.

Bundy, A. (ed.) (2004) Australian and New Zealand Information Literacy Framework principles, standards and practice, $2^{\text {nd }}$. ed. Adelaide: Australian and New Zealand Institute Information Literacy. 
INTERNATIONAL JOURNAL OF ACADEMIC RESEARCH IN PROGRESSIVE EDUCATION AND

DEVELOPMENT

Vol. 7, No. 3, July 2018, E-ISSN: 2226-6348 @ 2018 HRMARS

Cassidy, S. and Eachus, P. (1998), "Developing the computer self-efficacy (CSE) scale: investigating the relationship between CSE, gender and experience with computers", Computer SelfEfficacy Web Site, available at: www.chssc.salford.ac.uk/healthSci/ selfeff/selfeff.htm (accessed 28 April 2003).

Convergence. $\quad$ Retrieved December 22, from https://www.techopedia.com/definition/769/convergence

Coolahan, J. (2002). Teacher education and the teaching career in an era of lifelong learning. OECD Education Working Papers, 2, 1-39.

Cunningham, J. (2010), "New workers, new workplace? Getting the balance right", Strategic Direction, Vol. 26 No. 1, pp. 5-6.

Cherry, E, Rollins, SH, Evans, T (2013) Proving our worth: The impact of electronic resource usage on academic achievement. College \& Undergraduate Libraries, 20(3-4): 386-398.

Demiralay, R., \& Karadeniz, Ş. (2008). Developing information literacy skills for lifelong learning in elementary education. Cypriot Journal of Educational Sciences, 2 (6), 89-119

Demirel, M. (2009). Implications of Lifelong Learning on Educational Institutions. Cypriot Journal of Educational Sciences, 4, 199-211

Diehm, R. A. and M. Lupton. 2014. Learning information literacy. Information Research, 19(1).

Dunford, H. (1998), "Cooperation, compromise, commitment: a joint use library in an isolated area of Tasmania", Australasian Public Libraries and Information Services, Vol. 11 No. 4, pp. 179-81

Frau-Meigs, Divina (2012) " Transliteracy as the new research horizon for media and information literacy", Media Suites, Vol. 3 Issue: 6, pp.14-27,

Hargittai, E. (2010), "Digital na(t)ives? Variation in internet skills and uses among members of the 'net generation'”, Sociological Inquiry, Vol. 80 No. 1, pp. 92-113.

Jarvis, P. (Edit.) (2009). The Routledge International Handbook of Lifelong Learning. USA: Routledge

Information literacy. Retrieved November 11, 2017, from www.businessdictionary.com/definition/information-literacy.html

John-Steiner, V. \& H. Mahn. 1996. Sociocultural approaches to learning and development: A Vygotskian framework. Educational Psychologist, 31(3): 191- 206. 
INTERNATIONAL JOURNAL OF ACADEMIC RESEARCH IN PROGRESSIVE EDUCATION AND

DEVELOPMENT

Vol. 7, No. 3, July 2018, E-ISSN: 2226-6348 @ 2018 HRMARS

Johnston, N. (2010), "Is an online learning module an effective way to develop information literacy skills?”, Australian Academic \& Research Libraries, Vol. 41 No. 3, pp. 207-218.

Kear, M. (2000), "Concept analysis of self-efficacy", Graduate Research in Nursing, available at: http://graduateresearch.com/Kear.htm (accessed 8 April 2003).

Koltay, T., Krakowska, M., Landova, H. and Pro'kai, M. (2010), "Information literacy in the Visegrad group countries: literature and initiatives", Education for Information, Vol. 28 No. 1, pp. 57-76.

Koul, R. and Rubba, P. (1999), "An analysis of the reliability and validity of personal internet teaching efficacy beliefs scale", Electronic Journal of Science Education, available at: http:// unr.edu/homepage/crowther/ejse/koulrubba.html (accessed 27 December 2002).

Ladbrook, J. and Prober, E. (2011), "Information skills and critical literacy: where are our digikids at with online searching and are their teachers helping?", Australasian Journal of Educational Technology, Vol. 27 No. 1, pp. 105-121.

Lave, J. (1988). Cognition in practice: Mind, mathematics, and culture in everyday life. Cambridge: Cambridge University Press.

Lemke, J. L. (1990). Talking science: Language, learning, and values. Norwood, New Jersey: Ablex Publishing Corporation.

Limberg, L. (1999), “Experiencing information seeking and learning: a study of the interaction between two phenomena", Information Research, Vol. 5 No. 1, available at: http:// informationr.net/ir/5-1/paper68.html (accessed 12 October 2008).

Meadow, C.T. and Yuan, W. (1997), "Measuring the impact of information: defining the concepts", Information Processing and Management, Vol. 33 No. 6, pp. 69-714.

Maehl, W.M. (2003), "Lifelong learning", in Guthrie, J.W. (Ed.), Encyclopedia of Education, Macmillan, New York, NY, pp. 1480-3.

Nuthall, G. 1997. Understanding student thinking and learning in the classroom. In B. J. Biddle, T. C. Good \& I. Goodson (Eds.), The International Handbook of Teachers and Teaching (pp. 681-768). Dortrecht: Kluwer Academic publishers.

Pajares, F. (2002), "Overview of social cognitive theory and of self-efficacy", available at: www.emory.edu/EDUCATION/MFP/eff.html (accessed 26 December 2002).

Rogoff, B. (1990). Apprenticeship in thinking: Cognitive development in social context. New York: Oxford University Press. 
INTERNATIONAL JOURNAL OF ACADEMIC RESEARCH IN PROGRESSIVE EDUCATION AND

DEVELOPMENT

Vol. 7, No. 3, July 2018, E-ISSN: 2226-6348 @ 2018 HRMARS

Rogoff, B. (2003). Cultural nature of human development. New York: Oxford University Press

Rowlands, I., Nicholas, D., Williams, P., Huntington, P., Fieldhouse, M. and Gunter, B. (2008), "The Google generation: the information behaviour of the researcher of the future", Aslib Proceedings, Vol. 60 No. 4, pp. 290-310.

Salisbury, F. and Karasmanis, S. (2011), "Are they ready? Exploring student information literacy skills in the transition from secondary to tertiary education", Australian Academic \& Research Libraries, Vol. 42 No. 1, pp. 43-58.

Shapiro, J.J. and Hughes, S.K. (1996), "Information technology as a liberal art", Educom Review, Vol. 31 No. 2, pp. 31-6.

Sonja Spiranec, Mihaela Banek Zorica, (2010) "Information Literacy 2.0: hype or discourse refinement?", Journal of Documentation, Vol. 66 Issue: 1, pp.140-153, https://doi.org/10.1108/00220411011016407

Toteng, B., Hoskins, R. and Bell, F. (2011), "Information literacy and law students at the University of Botswana", Mousaion, Vol. 29 No. 1, pp. 56-75.

Vygotsky, L. S. (1978). Mind in society: The development of higher psychological processes. Cambridge: Harvard University Press.

Vygotsky, L. S. (1986). Thought and language. Cambridge: M.I.T. Press, Massachusetts Institute of Technology.

Wilson, T.D. (1999), "Models in information behaviour research", Journal of Documentation, Vol. 55 No. 3, pp. 249-70.

Whiteside, A. L. 2007. Exploring social presence in communities of practice within a hybrid learning environment: a longitudinal examination of two case studies within the school technology leadership graduate-level certificate program. Unpublished PhD, University of Minnesota, Minnesota. Retrieved from ProQuest Dissertations \& Theses database.

Woods, J.A. (2001), "Joint-use libraries: the Broward Community College central campus experience", Resource Sharing and Information Networks, Vol. 15 Nos 1/2, pp. 41-53.

Wertsch, J. V. 1991. Voices of the mind: A sociocultural approach to mediated action. London: Harvester Wheatsheaf

Wilkes, J. and Gurney, L.J. (2009), "Perceptions and applications of information literacy by first year applied science students", Australian Academic \& Research Libraries, Vol. 40 No. 3, pp. 159-171. 